\title{
Children's consumption culture development through Christmas myths: ethical implications
}

\author{
Ann-Marie Kennedy, Martin K.J. Waiguny and Maree Alice Lockie
}

\begin{abstract}
Purpose - This paper seeks to explore the functions of Christmas mythemes for children's consumption culture development. In addition, the purpose of this study is to provide an insight on the development of Central European Children into customers and how mythemes are associated with the wishing behaviour.

Design/methodology/approach - Levi-Strauss' (1955) structural analysis was used to uncover the mythemes of the Christmas story for Austrian children. These mythemes then informed a thematic analysis of 283 Austrian children's Christmas letters. Campbell's (1970) functions of myths were used to reflect on the findings.
\end{abstract}

Findings - The Christmas mythemes uncovered were found to encourage materialism by linking selfenhancement (good acquirement) with self-transcendent (good behaviour) values. The role of myths to relieve the tension between the incongruent values of collective/other-oriented and materialistic values is expanded upon. Such sanctification of selfish good acquisition is aided by the mythemes related especially to the Christkind and baby Jesus. Instead, marketers should use Christmas mythemes which emphasise family and collective/other-centred values.

Originality/value - By first uncovering the "mythemes" related to Christmas, the authors contribute to the academic understanding of Christmas, going beyond origin or single myth understandings and acknowledging the multifaceted components of Christmas. The second contribution is in exploring mytheme's representation in children's Christmas letters and reflecting on their functions. This differs from previous literature because it looks at one of the main cultural vehicles for Christmas socialisation and its intersection with the mythemes that feed children's consumption culture formation. Through the authors' presentation of a conceptual framework that links mytheme functions with proximal processes using a socioecological viewpoint, the authors demonstrate the guidance of mythemes in children's development. The third contribution is a reflection on the potential ethical implications for children's formation of their consumer culture based on the functions of the mythemes. Furthermore, the authors add to the existing body of research by investigating a Central European context.

Keywords Mythemes, Children, Consumption, Structural analysis, Thematic analysis, Materialism, Self-enhancement, Self-transcendent, Myths, Qualitative methods, Consumer socialisation,

Purchase requests

Paper type Research paper

\section{Introduction}

This festival teaches even the little children, artless and simple, to be greedy and accustoms them to go from house to house and to offer novel gifts, fruits covered with silver tinsel. For they receive, in return, gifts double their value and thus the tender minds of the young begin to be impressed with that which is commercial and sordid. (Bishop Asterius of Amasea, 400AD in Oratio 4: Adverservus Kalendarum Festum)

Children become consumers in advanced Western economies through a complex, multilayered, process of learning (Cram and Ng, 1999; Dotson and Hyatt, 2000; Hayta, 2008; Ward, 1974). One element of children's consumption culture development are stories and
Ann-Marie Kennedy is based at University of Canterbury, Christchurch, New Zealand.

Martin K.J. Waiguny is based at IMC University of Applied Sciences Krems, Krems, Austria.

Maree Alice Lockie is based at One Picture New Zealand, Auckland, New Zealand.

Received 31 May 2021 Revised 12 August 2021 16 October 2021 Accepted 23 October 2021

(C) Ann-Marie Kennedy, Martin K.J. Waiguny and Maree Alice Lockie. Published by Emerald Publishing Limited. This article is published under the Creative Commons Attribution (CC BY 4.0) licence. Anyone may reproduce, distribute, translate and create derivative works of this article (for both commercial \& non-commercial purposes), subject to full attribution to the original publication and authors. The full terms of this licence may be seen at http:// creativecommons.org/licences/ by/4.0/legalcode 
narratives (Blanchet, 2020). Children's interaction and interpretation of aspects of culture, including related objects and symbols, are proximal processes and contribute to their human development (Bronfenbrenner, 1995). As part of the socioecological model of human development, they may be exposed to these via family, friends, community, media and marketers among others (Eisenmann et al., 2008).

Even though Bettelheim (1976) outlines the importance of fairy tales and stories for the socialisation of children, children's Christmas gift requests have only been quantified in literature (Ganassali, 2019; O'Cass and Clarke, 2002; Otnes et al., 1994; Martínez-Pastor et al., 2013; Richardson and Simpson, 1982; Robertson and Rossiter, 1976). Along with their relationship to advertising (Buijzen and Valkenburg, 2000; Pine et al., 2007; Witkowski, 2020), overall studies on the meaning of Christmas have largely focussed on adults (Clarke, 2007; Hirschman and LaBarbera, 1989; Tynan and McKechnie, 2005).

A deeper understanding of the potential influence on children's formation of their consumption culture from such a commercial yet spiritual holiday is needed. This is especially important given that children are in the key Christmas fantasy age group (4-12 years) and may not be able to process the symbolic nature (John, 1999) of Christmas gifts. Instead, their interpretation is that good behaviour begets goods, and this is translated into a life rule. Also, anonymous gifts (for example, from Santa) take away the usual norm learning associated with gift giving such as reciprocity and affection (Hagstrom, 1966). Previous research has considered the content of children's Christmas letters but not applied theory as to how or why value creation occurs or the ethical implications of that for marketers. This research addresses that gap and theorises the implications of this value creation for the development of children's consumer culture.

In relation to religious feasts, narratives like the story of Father Christmas are used by adults to introduce values and induce behaviour in children. As Gill and Papatheodorou (1999) emphasise, stories are also part of family traditions celebrated on holidays. An investigation of these narratives should uncover conflicting but also complementary narratives surrounding Christmas which contribute to children's consumer culture formation. From a marketing perspective, we need to understand common narratives and myths used in marketing, as marketing efforts start as early as three to four months prior to Christmas and expenditures are at all-time highs (Dautovic, 2020; Broom, 2019).

As Christmas and many of its origins are seen as myths (Belk, 1987; Lévi-Strauss, 1993), the approach taken by Lévi-Strauss (1955) to structurally analyse myths into their component parts is taken. This uncovers the deeper meanings of Christmas and allows for the inclusion of the many myths that make up Christmas for a child of Europe to be included (specifically here we look at Austria). The overall aim of this research is to discuss the role of Christmas and Christmas myth themes as agents for children's formation of their consumption culture with ethical implications.

Therefore, we investigate which stories in the course of Christmas socialise children and what deeper mythical themes are related to them. The actual historical or anthropological development, while being interesting, is not the focus of this paper, rather the children's stories. The influential aspects of the myths are then reflected upon using Campbell's four functions of myths - metaphysical, cosmological, sociological and psychological guidance (Campbell, 1970).

By first uncovering the "mythemes" related to Christmas, we contribute to the academic understanding of Christmas, going beyond origin or single myth understandings and acknowledging the multifaceted components of Christmas. Our second contribution is in exploring mytheme's representation in children's Christmas letters and reflecting on their functions. This differs from previous literature because it looks at one of the main cultural vehicles for Christmas socialisation and its intersection with the mythemes that feed children's consumption culture formation, thus exploring and uncovering the links between 
them. As stated by McKechnie and Tynan (2006) such understanding is needed in order for us to understand more about consumers and add to consumer culture theory (Hirschman and LaBarbera, 1989). This further contributes to theory in human development through our presentation of a conceptual framework that links mytheme functions with proximal processes using a socioecological viewpoint. Our third contribution is a reflection on the potential ethical implications for children's formation of their consumer culture based on the functions (Campbell, 1970) of the mythemes.

\section{Christmas as agent in children's consumption culture creation}

John (1999) identifies family, culture, mass media and marketing as areas that influence consumer socialisation and that are in need of further study. Christmas has been identified as one such consumer socialisation agent (Belk, 1987) that encompasses all of these areas. Christmas has been shown to exemplify norms including gift giving (Hagstrom, 1966; Caplow, 1984), social power (Moschetti, 1979; Wolf, 1964; Hagstrom, 1966), as well as materialism and excess (Pollay, 1987; Belk, 1987; Hagstrom, 1966; Mckay, 2008). Specific rituals that create meaning at Christmas have been identified by Tynan and McKechnie (2005) as happening for adults through fantasising, reminiscing, socialising, communing, possessing, grooming, exchanging, divesting, anticipation and entertaining; whereas the meaning of Christmas for American adults has been found to include themes of religion, interpersonal relationships, secular materialism and commercialisation, gift-giving, sensuality and hedonism (Hirschman and LaBarbera, 1989; Bartunek and Do, 2011). Christmas gifts carry and transfer different meanings to their recipients. For adults, this is usually meanings of affection to their family members (Carrier, 1993). To the authors' best knowledge, no such studies have been conducted for children and indeed, given that children are still developing these associations with Christmas, are in all likelihood unable to be replicated.

Focusing on children, it has been found that believing in such a "fantasy" as Christmas myths is healthy in helping them to identify reality as adults (Bettelheim, 1976), though they are less likely to believe in them after 8 years of age (Prentice et al., 1978). Previous studies on letters to Santa find that children are "little consumers in training" as they specifically request branded products (Otnes et al., 1994; O'Cass and Clarke, 2002; Halkoaho and Laaksonen, 2009). Caron and Ward (1975) analysed gift requests and found middle class children asked for things they could use by themselves, generally from Santa, while upperclass children asked for competitive and sporting items, generally from their parents. Stereotypical gender specific requests have also been found (Richardson and Simpson, 1982; Downs, 1983; Martínez-Pastor et al., 2013) as has a correlation between children's requests for Christmas and the advertising they watch (Buijzen and Valkenburg, 2000; Pine and Nash, 2002; Pine et al., 2007). Ganassali (2019) recent study showed, through a quantitative content analysis of French children's letters, that generally requests themselves are quite heterogenous. Four types of child consumer were represented within the letters: gourmets, educated, brand name droppers and sweet tooth, based on the brands and products named. Though while this segmentation has occurred, the values and how they are incorporated into a child's developing consumer culture has not been addressed.

The gap in the literature therefore shows that, while the content and in particular the requests, of children's Christmas letters has been described in many studies, the values related to the development of their consumer culture has only been sparsely considered and without strong theoretical bases. Overall, it is anecdotally accepted that Christmas teaches children that if they behave, they will be rewarded by receiving goods, thus allowing them to participate in a consumer society, using their behaviour as currency (Wolf, 1964). However, if, how and why this occurs and the ethical implications of that for marketers has not been researched. 


\section{Methodology}

The epistemological stance of the researchers is constructionism. The researchers believe that knowledge and reality are constructed by interaction with and interpretation of the world and so are influenced by social contexts (Crotty, 1998). Our interpretivist stance "looks for culturally derived and historically situated interpretations of the social life-world" (Crotty, 1998) which was achieved through a hermeneutical approach allowing us to explore the hidden meanings of myths (Kearney, 1991). Thus our method consisted of four steps:

1. collation of relevant myths and stories to inform the structuralist approach of LéviStrauss (1955);

2. thematic coding of relevant myths from text and images provided in the collected letters;

3. clustering, forming and interpreting the binary-pairs of mythemes from the structuralist method; and

4. relating them in a holistic conceptual framework to their functions in respect to forming consumer culture in children.

\section{Investigating myth}

A myth is a story that explains how to interpret and conduct oneself in the world (Stern, 1995). The meanings of myths will be explored using Lévi-Strauss (1955) structuralist method. Myths were chosen to be studied because they are carriers of the values inherent in a culture and have been seen as socialisation agents (Hirschman, 1987). The structuralist approach helps to systematically examine the relationship between themes in a myth and provides a way of comparing myths and their transmission objects (i.e. letters; Hirschman, 1987).

Lévi-Strauss' (1955) structuralist approach is different from a content-based analysis as it allows the basic propositional themes to be uncovered versus potentially fitting pre-determined themes to the myths (e.g. taxonomy of Frye, 1957). The binary opposites identified using Lévi-Strauss' (1955) method help to uncover the metalanguage which influences everyday understanding about behaviour and so provide a theoretical contribution from our research. These myths may transmit the base values surrounding consumption in a culture (Levy, 1981; Sherry, 1987). Everyday adult consumption myths have been explored by Levy (1981) and Hirschman (1988), but the next step is to explore the links between those myths and children's consumption culture creation. Thus, we uncover the social values that myths transmit to children, by looking at children's own expressions of these values in their Christmas letters.

We then discuss the four functions (Campbell, 1970) of these mythemes and reflect on their implications. These functions are as follows:

- metaphysical - which looks at our relationship with the supernatural or unknown;

- cosmological - covering our relationship with the universe and the order of its physical elements;

- sociological - in as our relationships with one another and the social order and lastly to provide; and

- psychological guidance - to become the best version of ourselves and deal with everyday problems. 


\section{Identification of mythemes}

The Christmas myth was chosen due to its identification in the literature as a myth (Belk, 1987; Lévi-Strauss, 1993) and as a consumer socialisation agent (Belk, 1987) and due to the sacralisation of the commercial component of the festivity (Bartunek and Do, 2011). Christmas therefore blends mythical, religious and commercial aspects around the world (Deacy, 2016; Miller, 2017). Despite the pagan and Christian roots of the Christmas celebrations (Deacy, 2016; Kriechbaum, 2010; Miles, 1912; Miller, 2017) the festive events of today are founded in the Victorian times (Miller, 2017) and the customs of pre-1848 revolutionary Germany and Austria (Kriechbaum, 2010; Laing and Frost, 2015). Austria is the context of this study, and so the prevailing stories that create the myth of Christmas for children were identified as: Saint Nicholas, Santa Claus, Christkind(lein), Krampus and the birth of Jesus Christ (Appendix, for example, summaries of these stories). Though there is slight variation between regions (Kriechbaum, 2010), these choices were supported by the literature (Weber-Kellermann, 1978; Vernaleken, 1859; Kriechbaum, 2010; Belk, 1987; Ridenour, 2016; Laing and Frost, 2015). Literature, in particular local stories and legends around the Krampus and other characters (for summaries see Ridenour, 2016), lyrics (Brauer, 2019) and illustrations in both English and German were sought on these myths to undertake the structural analysis. As well as a review on other traditions like Christmas markets were considered (Broeckerhoff and Galalae, 2020).

Following Lévi-Strauss' (1955) method, many versions of the myth were first collected. Myths were divided into sentences, grouped by themes and organised by their binary opposites. These interpretations were also informed by reading expert opinions on the myths, along with their origins and evolutions. This was continued until repetition occurred (Lévi-Strauss, 1955; Levy, 1981), indicating saturation. Themes and their binary opposites are called mythemes. They are generic units of a narrative structure to construct a myth. Once identified, mythemes were used to undertake a thematic analysis of children's Christmas letters. A similar approach to such consumption artefacts was taken by Levy (1981).

\section{Data collection}

Christmas letters were chosen as the data source for this research due to the unobtrusive nature of these letters, which ensures a naturalistic setting and does not bias the children (Lincoln and Guba, 1985). Children's Christmas letters are also cultural artefacts that provide an understanding of children that is hard to find through traditional methods (Otnes et al., 1994). Furthermore when writing letters there is usually no direct moral feedback, such as giving Christmas gift wishes to Santa at the mall (Theobald et al., 2018).

Parents were asked in a newspaper advertisement for a copy of their children's Christmas letters and in return were put into a draw for three gift vouchers valued at $€ 50, € 100$ and $€ 150$. Additionally teachers at primary schools were invited to notify children and parents to participate, after consent from the school authorities and principal was obtained. Any identifying information, except for age and gender, has been excluded. 250 letters were obtained with parental, principal and school authority approval in a first larger data collection. Similar to other studies (Ganassali, 2019), letters written by parents (e.g. without syntax and spelling mistakes or with too developed hand writing or purely machine written letters) have been discarded. The letters feature many drawings and are either in a conversational or traditional letter style or a list.

To ensure dependability and confirmability of this first larger sample, a second sampling via social media (Instagram) with the search strategy \#briefanschristkind, \#Christkindbrief as well as a posting board on the university's intranet for uploading Christmas letters of children added another 33 letters to the collection. Despite naming different requests, the 
styles and drawings of the additional sample are comparable to the prior sample; thus, the two samples were merged after confirming the identified mythemes for further reporting.

\section{Trustworthiness}

Trustworthiness of the current study is established based on the four criteria outlined by Lincoln and Guba (1985). Credibility was sought through source and investigator triangulation as described above. The mythemes were double checked with theological, anthropological, sociological and historical analyses. Furthermore, the later sampled letters the data revealed no new pairs of mythemes. As generalisability requires the belief in one "truth", it is not an appropriate concept to apply when a constructionist epistemology is held by the researchers (Lincoln and Guba, 1985). Instead, transferability is more appropriate as it corresponds with constructionist beliefs in that it allows for transferability of findings to other contexts if those contexts are similar enough to the future context of study. As such generalisability can only be judged on a case-by-case basis using the findings and research context. Transferability is sought through the thick description provided in the findings section, which allows future researchers to judge whether their contexts are similar to the present one and thus the findings generalisable to their specific context. Dependability and confirmability were established through an audit of all sources and interpretations by an expert in the area that was not an author of the article. Agreement on interpretations was achieved.

The Christmas myths covered in this research are Jesus' birth, Santa Claus, St Nicholas, the Krampus and Christkindlein. In the findings section that follows, we first present the mythemes from the Christmas myths. Finally, we explore the representation of those mythemes in the Austrian children's Christmas letters. The discussion section provides reflections on the functions of the mythemes and implications for a child's consumption culture development and ethical implications of the findings for marketers.

\section{Findings}

We now explain these mythemes and provide exemplar quotations of their representation in the Children's Christmas letters. Children have been anonymised and so quotations are followed with an "M" for male or " $\mathrm{F}$ " for female, along with the number assigned their letter. Following this is a reflection on the functions of the myths and discussion of how our findings sit within the extant literature. The three mythemes pairs uncovered can be seen in table 1 . As also mentioned by other researchers (Deacy, 2016; Scheer, 2019), the narrative and myths around Christmas are conflicting or bidirectional opponents but they exist at the same time. Thus, we also found elements of the three presented pairs within the letters.

\section{First pair: Earthly/material and transcendental}

The first set of mythemes can be broadly termed Earthly and Transcendental. In both Santa's tale and Jesus birth, the characters are humanised. Earthly material abundance is seen especially in Santa with his obese figure and royal clothing, along with his giving of toys to children (Belk, 1985, 1987, 1993; Pimlott, 1962; McKechnie and Tynan, 2006). The love of material goods is perpetuated for children in writing their wish list of gifts to Santa

\section{Table 1 Christmas mythemes}

\begin{tabular}{lll} 
First pair & Second pair & Third pair \\
\hline Transcendental & Selflessness & Rewards \\
Earthly/Material & Selfishness & Punishment
\end{tabular}


(Caplow, 1984; Hirschman and LaBarbera, 1989; Belk, 1993; Halkoaho and Laaksonen, 2009) or the Christkind.

The opposite to this, transcendental mythemes surround the holy incarnation of Jesus (Belk, 1993; Hirschman and LaBarbera, 1989; Miles, 1912). Santa also carries aspects that relate to this transcendental mytheme: He is magic, lives forever, has a flying sleigh, endless toy sack and can deliver toys to every child in the world in one night (Belk, 1993). Particularly in the Austrian culture, there is quite a differentiation in terms of transcendental and earthly, and they are represented by baby Jesus vs the Christkind. Baby Jesus as described above is the earthly born person, while the Christkind is to a certain extent magic and more angel like Schori (2008), Ridenour (2016). While religious aspects are related to Baby Jesus, the Christkind is related solely to gift giving and organising Christmas Eve. Unlike Santa, a strong personification of the Christkind in shopping malls or markets is not that common, the Christkind is more a magical and mystic figure. Only adults can see the Christkind, and a child's letter to the Christkind magically disappears from their windowsill. Another aspect of transcendental and earthly are the rituals around St. Nicholas. The earthly component is that St. Nicholas and the Krampus actually visit homes to reward and punish children, but both are also transcendental, as particularly the Krampus steals the children away to hell (Kriechbaum, 2010; Ridenour, 2016). Even the very act of receiving gifts from the various characters epitomises the earthly mytheme in Christmas, while the belief in something existing outside of the earthly realm - Santa, Jesus/God, Christkind, Krampus - speaks to the transcendental mytheme overall.

The earthly/material mytheme is the most prominent in the Christmas wish letters; almost all of them present wishes for earthly possessions; only mere $4.6 \%$ did not feature earthly/material content. Most of the letters feature either drawings of the gifts requested (Figure 1) or collages of gifts requested from catalogues (e.g. M108, F110, M111, F200, F204, M258, F264; Figure 2).

Many are lists of toys with no salutation at all (e.g. M55, F58, F107, M133, M265, F273). Use of "I want [...]" or "I wish [...]" accompanied by a list of gifts or a range of drawings of them is very common (e.g. F64, M104, M105, M106). Beyond these obvious earthly themes, we have other direct materialistic links where goods will bring the child happiness:

I would be really happy with a mini-motor cross [.. .] (M40),

I would be happy with a Nintendo game (M44).

\section{Figure 1 Drawings and collages of requests}

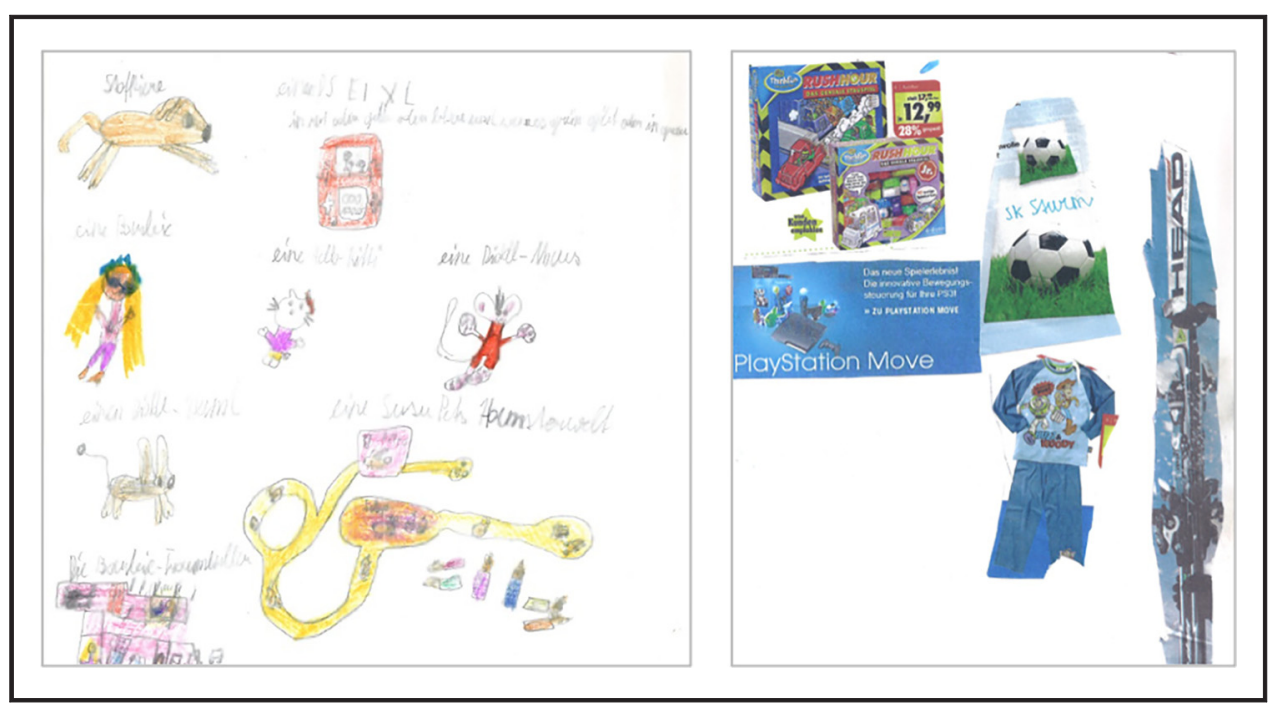




\section{Figure 2 Transcendental elements in the letters}

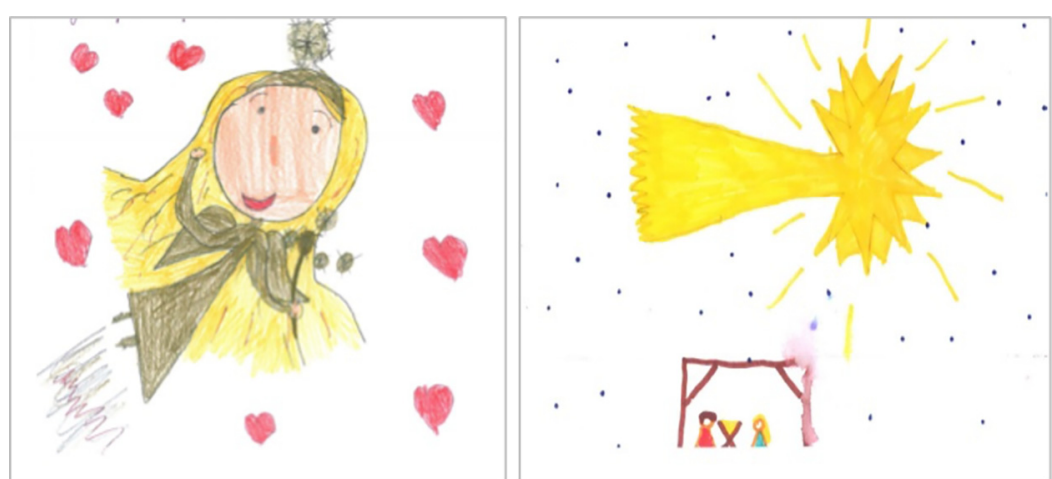

And even remind the Christkind not to miss a wish by adding,

Skinny, please do not forget it (F261)

Transcendental elements are seen with the many pictures of the children. We see religious pictures of the nativity scene (Figure 2; e.g. F14, F18, F39, F96) and advent reef (e.g. F52, M53). We also see pictures of the Christkind as an angel with golden hair, wings and a wand (e.g. M28, M29, M234, F275, M277), even flying in the clouds (Figure 2; e.g. M20). Santa Claus is depicted with his sleigh as well (e.g. M63). Beyond these simple relations however we also find that children very easily represent more than one of the stories without tension in their drawings. Thus we found transcendental elements in $31.1 \%$ of the letters showing that in about a third of the letters transcendental and material coexist.

As children usually do not encounter the Christkind on Christmas Eve, they are of course curious and want to understand their transcendental nature, for instance asking for a picture:

Please send a picture of yours (M271)

But the transcendental mytheme also appears in unrealistic requests like:

I would be happy about a time-machine (M49)

Seeing these figures as godlike is realised not only in their use of the words "I wish" but also other heartfelt pleas such as:

Dear Christkind, I hope you hear and respond to my prayer; I wish for a miracle that my brother gets better [...] (F181).

Along with some other specific requests:

I wish that no animal is threatened by extinction, I wish that no one lies anymore [...] (M173).

[...] I wish for a baby. (F147)

[...] and some words from my disabled sister. (M232)

\section{Second pair: Selfishness and selflessness}

A way to achieve transcendental or earthly and material outcomes can be seen in the second set of mythemes which are Selflessness and Selfishness. Selflessness is seen in the stories of St Nicholas and Jesus who gave without seeking rewards (Belk, 1987; Miles, 
1912). For children to be kept safe from the Krampus they also must behave well, one aspect of which is selflessness (Kriechbaum, 2010; Ridenour, 2016). Paradoxically, for children to gain the material possessions they want, they are encouraged to be selfish. Writing letters to Santa or the Christkind asking for gifts for themselves, not others, can be seen as selfish behaviour.

These two mythemes can be understood more using the conceptualisation of selfenhancement and self-transcendence originally from Schwartz (1994) and developed further by Burroughs and Rindfleisch (2002). In the concept of self-enhancement, we see aspects of self-oriented/selfish values. Examples include hedonism, power and materialism. We can see the link between these values and our mythemes of both selfishness and earthly/materialism: hedonistic aspects of the rich and luxurious clothing of Santa and the crown of the Christkind, the materialistic requests made of both of those characters also and the power epitomised in both Santa or the Krampus to deny children their gifts.

The concept of self-transcendence introduces the examples of benevolence, universalism, religiosity and family as collective-oriented values (Burroughs and Rindfleisch, 2002; Schwartz, 1994), which link to our transcendental and selfless mythemes. Concern for family is seen in St Nicholas' saving of the three daughters, while concern for the world is seen in Santa bringing gifts for the world. The Christkind decorating to create a good family Christmas and the family surrounding the baby Jesus help us to see the collective oriented family values.

While selfishness can be seen in the lists of gifts provided in the letters very often with prioritising one request over the others by ranking them (e.g. M199, M258) or highlighting what is important (e.g. M268, W274) and the use of the words "I want", 96.1\% of the letters contained clearly elements with selfishness mostly by emphasising what they want; however, some were even more elaborate; thus, we have some further examples to show the egocentric focus of many of the letters in:

[...] I wish myself good health. (M40)

This can be expanded upon by the aspects of self-oriented values as well where hedonism and power themes were also seen within the letters. For instance, hedonistic aspects of fun and play can be seen in Figure 3 where a child not only asks for a bobsled but draws a picture of the bobsled's tracks when they use it (M19).

Or with this child's single request:

I wish for internet access at home so I can play. (M143)

Or this expanded request:

Dear Christkind, I wish for a game called "Megamind". I find it fascinating because you control it with your thoughts. (F203)

Or in this quote:

Dear Christkind, I wish for 10000 Euro and a cape to play superheroes. (M175)

For power over the negative aspects of the Christmas story, the Krampus is also sought by the children. One letter depicts the Krampus who is being shot by a tank (Figure 4, upper right corner red mask) while others request Krampus costumes (M247) to become the bringer of punishment rather than be controlled, by listing:

Krampus fur, a Krampus belt and the Krampus gloves [...] (M237)

[...] and a cool mask [...] accompanied by a picture of the Krampus mask (M238)

Opposite to these selfish, self-oriented themes were present in $12.7 \%$ of the letters; we can see the selfless, other-oriented themes also in many of the letters. For instance, these sole requests: 


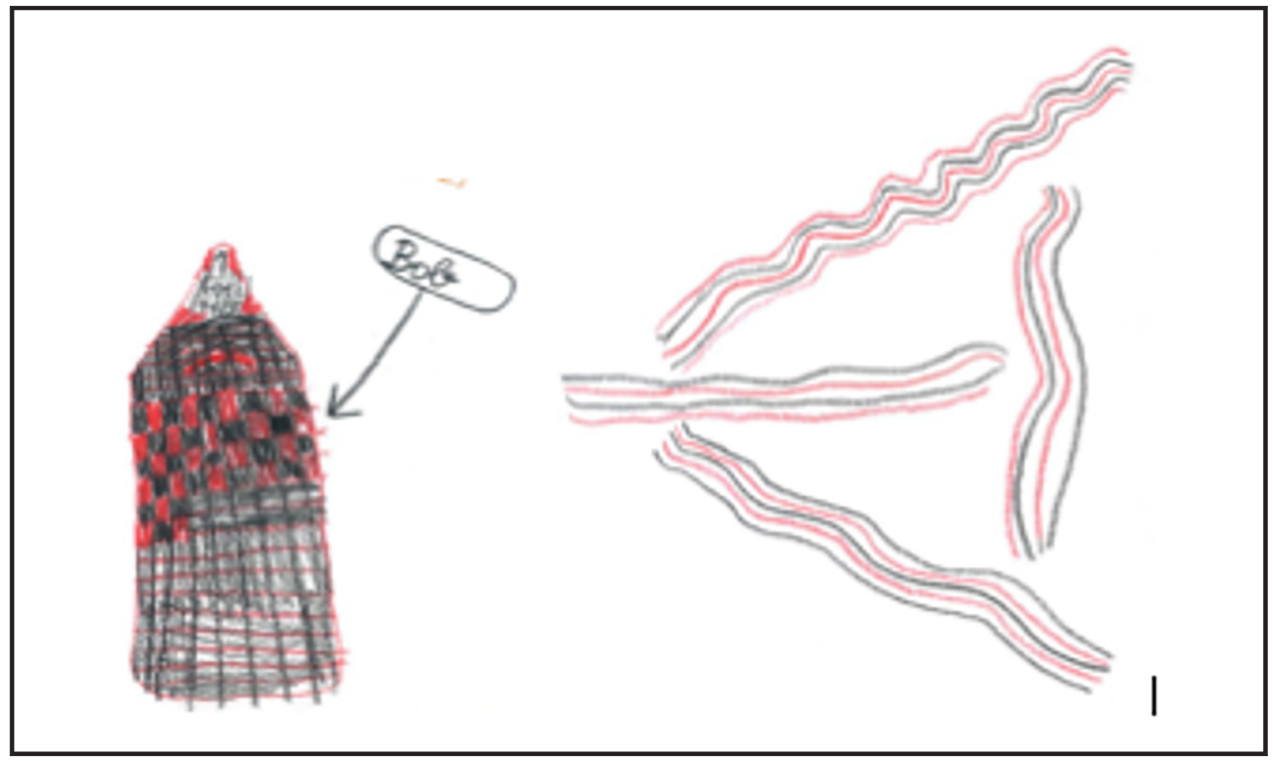

\section{Figure 4 Elements of self-oriented-values - power}

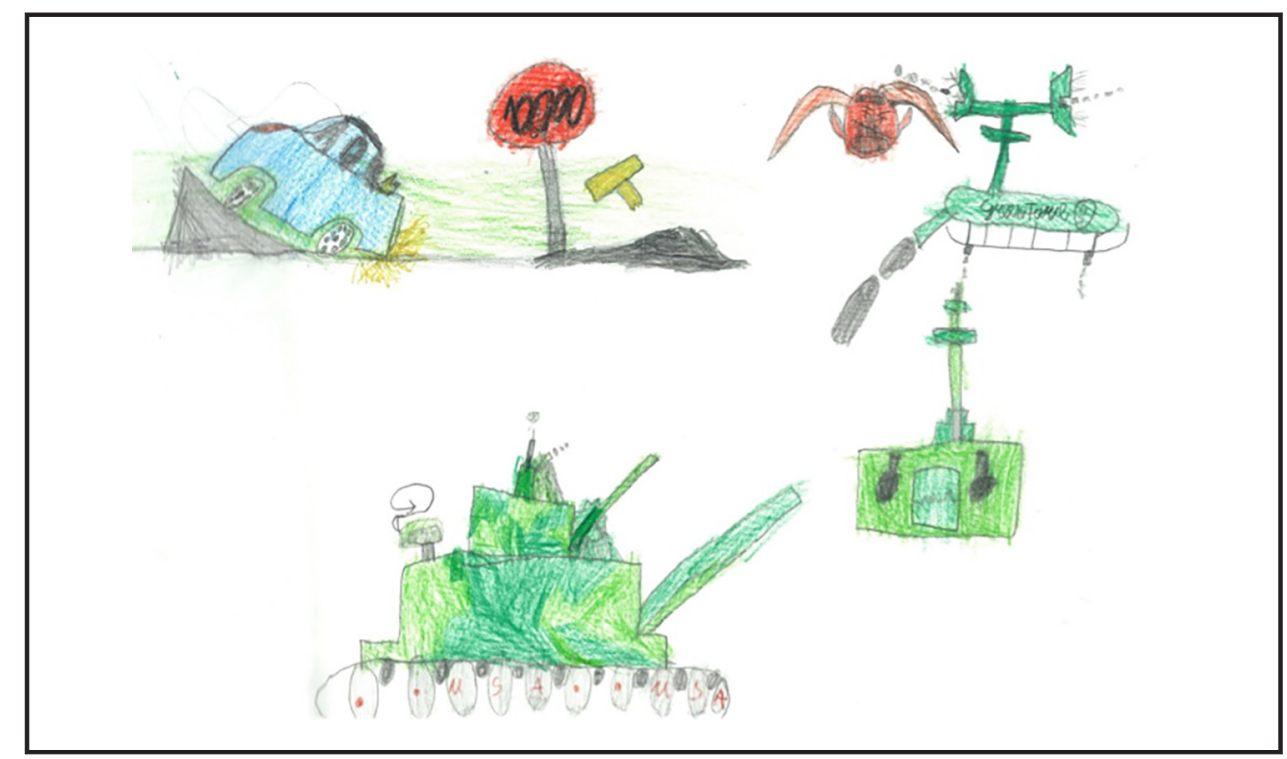

I wish for Christmas that we are all together. (F149)

Dear Christkind, I wish everyone a merry Christmas. (F39)

Along with specific benevolent requests such as:

Dear Christkind, I wish for peace and love in my family [ . . ] (F64)

Dear Christkind, I wish for Christmas that my family keeps in good health [...] (F171)

Dear Christkind, I hope you do not have Corona. (F278) 
Many of the letters featured drawings and references to family (Figure 5; e.g. M28, F45, F98) including a reference to "besinnlicher abend", which loosely translates to a contemplative evening with the family sitting together, singing together and looking forward to Christmas in a calm and relaxed environment highlighting also the selflessness within a family celebration.

And the heart-warming previous quote:

[...] and some words from my disabled sister. (M232)

More universal requests are also apparent such as:

I wish that there would be peace in the whole world [...] (F44)

$[\ldots]$ I wish that everyone is as well off as us. (F136)

Throughout the letters though, children easily present both self and other-oriented requests without tension. Often within lists, there is no particular order to these, such as with these multiple requests:

[...] bed linen with dolphins and one with rabbits and cats etc, that no one lives in poverty [...] that no one lies anymore, for a connect the dots game, that no one is mean anymore [...] and that everyone is in a good and happy mood for Christmas. (F173).

[...] I wish there are no very sick or people in poverty. I wish for a Nintendo with some games and some books. The last thing I wish for is that my family stays in good health and there is no cruelty to animals. (F181)

Hello Christkind, this year I wish the following: A set where one can make rubber-balls themselves. That we are all happy. Magic Sand. Please send a picture of yours. A lot of hand tattoos, also for do it yourself, a dairy-book with code and a surprise. Please! Thanks! (M271)

\section{Third pair: Rewards and punishments}

A confusingly related pair of mythemes is that of Rewards and Punishments, reflecting the moral work that children undertake (Theobald et al., 2018) through reconciling Christmas

\section{Figure 5 Elements of self-oriented-values - benevolence}

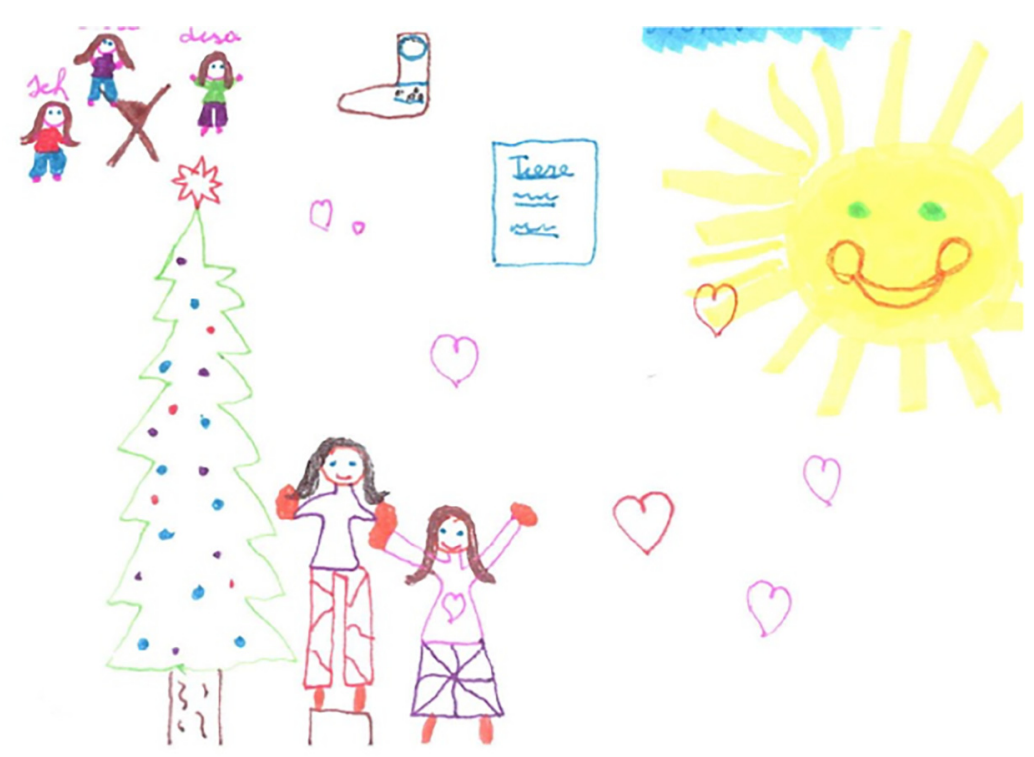




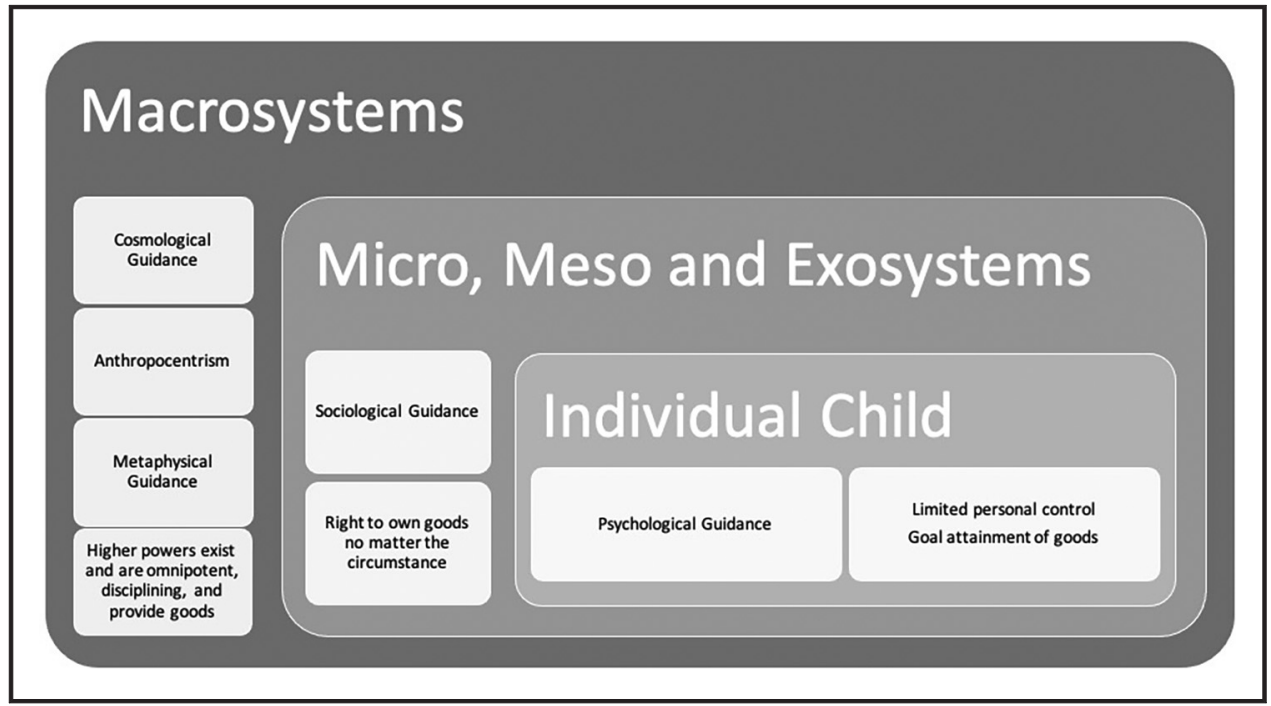

myths with their consumption cultures. Referring to the rewards and punishment mythemes in the letters, we find that there is really no mention of these in the letters directly though they can be inferred by statements such as the following:

Dear Christkind, I am pretty much always good, please bring me many many things. Here is my

list. Followed by three pages of requests (M215).

This statement though, of good behaviour, is rarely seen in the letters (F251, M254, F261). In all cases it is just mentioned that the child "had been good". While children grasp the concept of being rewarded for good behaviour by receiving goods very easily as we see the rewards theme in $8.8 \%$ of the letters, the punishment of not being given gifts is not seen at all only 2.1 of the letters address some form of punishment themes. This is illustrated in the usage of the word "bring" instead of wish (e.g. M11, M15).

Many letters are only lists of goods and nearly all do not feature a "thank you" (e.g. M99, M1, M105, M108, M110 etc). There is a clear expectation and feeling of their right to be given goods. This might be a result of the constructed myth of St. Nicholas and Krampus before Christmas, as children usually confess to St. Nicholas if they have been nice or naughty. Thus, the Christkind is reduced to the magical figure bringing presents. This also can be seen in some letters where pictures of the Krampus with gifts or even the Christkind happily coexist (M238, M239, M245).

Another interesting note is that requests are also used to maintain good behaviour like asking for a "tidy-up-robot" (M72). Potentially a tidier room likely leads to more rewards.

\section{Discussion}

Through this research we also view human development as phenomenological where influences are interpreted as such by each individual. Individuals are not passive receptors of their societal, life and historical contexts, but active participants in "shaping environments, evoking responses from them and reacting to them" (Darling, 2007, p. 204). According to Bronfenbrenner (1995), this can occur between a child and others, as well as through their interaction with symbols and objects, as has been researched here. These interactions within their immediate environment are termed proximal processes. As such, children's exploration of their environment and active interpretation results in different goals, 
values and beliefs (Bronfenbrenner and Ceci, 1994). These proximal processes amount in enduring influence through repetition Bronfenbrenner (1995). Such as is the case with Christmas and its associated symbols and objects interpreted within Christmas myths.

To further understand the socialising power of the Christmas mythemes identified in the findings (Earthly/material with transcendental; Selfish with selfless; Rewards with punishments) for Austrian children, we now turn to their functions and how those functions contribute to their development. The functions of the mythemes identified in the findings are first presented before being incorporated into a conceptual framework which explores and consolidates mytheme's functions in human development within a socio-ecological theoretical frame (Brofenbrenner, 1979). We then discuss their ethical implications for marketers.

\section{Functions of Christmas mythemes-conceptual framework}

Mytheme's metaphysical, cosmological, sociological and psychological functions (Campbell, 1970) will be covered. The metaphysical functions of a myth regard our relation to the supernatural. These are, that the mystical being associated with Christmas:

- [... ] can heal the sick, save animals and is omnipotent;

- [... ] rewards and punishes depending on the level of good behaviour; and

- $[\ldots]$ is a source of goods.

In this way, even though the mystical being is omnipotent (reflecting the transcendence theme), we try to gain control over the potential punishments (punishment theme) by killing or becoming the Krampus. The presence of the Krampus helps to teach responsibility and consequences for actions, however the lack of "follow through" with punishment is evident in the letters (punishment theme). Further by this mystical being bringing goods, goods are now sanctified and made acceptable (Earthly/material theme and rewards theme).

Human's relationships to the natural world are seen in the cosmological function of the mythemes (Campbell, 1970). We can see the following rule:

- We are above animals and wish to own or control them.

This anthropocentrism teaches us that we as humans above animals in nature's hierarchy (Earthly/Material and transcendence themes).

The sociological functions of the mythemes relate to the social norms, traditions and values presented. Here, we learn the following:

- I have been good and so deserve rewards of goods.

- I deserve goods and do not need to follow societal norms of grace to receive them.

- I do not have to earn goods; they are my right.

By reflecting on the different types of requests, we can see different social norms around goods. While some show that good behaviour earns goods (rewards theme), others imply they do not need to earn them; that whatever they do, goods are their right (selfish theme). They do not even have to say please and thank you, nor pay for goods, nor reflect on their cost; they are a right.

Finally, guidance in life is provided by the psychological function of these mythemes and uncovers rules such as:

- I cannot control everything and so must leave some things up to a higher power.

- Attaining goods is good. 
These were reflected in multiple themes including the selfless theme as well as rewards and selfish theme quotes.

We propose that the process of mytheme interpretation and application undertaken by children within their Christmas letters in the forms of metaphysical, cosmological, sociological and psychological guidance ARE proximal processes. These proximal processes are part of an iterative hermeneutic process of understanding through interactions with Christmas myths and the various other layers of influence including the micro, meso, exo and macrosystems. This is a new contribution to theory in the area of proximal processes from this research.

The child is at the centre of this figure as is the case for Brofenbrenner's Socioecological model of human development (Bronfenbrenner, 1995). The child has their own inner world which is surrounded by different levels of influential entities and aspects of their environment. However at an individual level, children provide themselves with psychological guiding principles - the limits to personal control and goal attainment of goods - based on their interpretation of the Christmas myths. We know that psychological guidance should be at the individual level because the guidance provided is for the own child's personal development and growth (Campbell, 1970). Sociological guidance that a child derives from Christmas myths - their right to own goods no matter the circumstance - is directly applicable to their functioning and relationships with others (Campbell, 1970). These principles are applicable to their interactions directly with others such as family members (microsystem level), the relationships between those they immediately interact with (mesosystem level) and those they don't directly interact with but still give influence such as mass media and marketers (exosystem level). Finally, macrosystems level principles refer to societal beliefs, values, norms and culture. As such, children's cosmological guiding principles around anthropocentrism match with the current dominant social paradigm and help them to understand their relationship with the universe and its physical elements. Finally, looking at their relationship with the supernatural or unknown (their metaphysical guiding principles) also fits within the macrosystem level and suggests higher powers exist and are omnipotent, disciplining and provide goods.

In essence our findings suggest that the identified Christmas myths serve several functions in the development of children as consumers. Providing guidance on one hand but also justification to attain goods (presents).

\section{Implications}

This article has set out to meet three objectives. The first two - to uncover the mythemes related to Christmas for Austrian children, explore their representation in children's Christmas letters and discuss the functions of those mythemes for a child's consumption culture development - have been fulfilled in the findings section. Our theoretical contribution surrounds the development of a conceptual framework which embodies the use of mytheme functions as proximal processes in human development. We now move on to discuss and reflect on these findings within the extant literature to better understand the implications of the use of these mythemes. We end with a reflection on the ethical implications of marketers' use of these mythemes in marketing to children, meeting our final objective.

Our findings broaden the academic understanding of Christmas as a consumption vehicle by looking at its socialising forces, rather than describing and identifying behaviours as is the case with Theobald et al. (2018), Ganassali (2019) and Tynan and McKechnie (2005). We also go beyond the histories of Santa Claus and the focus on American Christmases of previous studies (Barnett, 1954; Belk, 1987) to look at the polysemic Christmas story of Central-Europe, its parts and socialising potential, beyond gift-giving (Caplow, 1982). Our mythemes of Earthly/Material and Transcendental concur with aspects of the Secular- 
Positive and Sacred-Positive elements identified in adults by Hirschman and LaBarbera (1989) and the contradictions which Christmas presents (Broeckerhoff and Galalae, 2020). This has happened by looking at the natural interaction of children with Christmas through their letters. So beyond current findings that Santa leads to materialism (Belk, 1985, 1987), we are able to understand how this comes about: through the mingling of mythemes to relieve negative tensions surrounding materialism and the sanctification of goods by the Christmas deities. It is these findings, particular to children and removed from adult controlled aspects of Christmas such as excess of decorations (Pollay, 1987) large meals and extensive purchasing, which provide the major contributions of this article and will be discussed further now.

The function of myths (Lévi-Strauss, 1963) is to help humans to resolve conflicts and paradoxes apparent in the world and their existence. The role of a myth is to overcome life's contradictions (Lévi-Strauss, 1963) and we clearly see from the analyses that children use myth to cope with contradiction by combining different mythemes. We see how a consumer is created that equates goods as rewards for good behaviour and goods as a rite regardless of behaviour, perpetuating a consumer society rather than one where social relations and quality time are coveted. This speaks to the paradoxical nature of consumer interpretations of myths, where ascription to one aspect of a myth weakens another (Thompson, 2004) as well as the moral work that children undertake (Theobald et al., 2018).

Supporting Belk (1987) assertion that Santa Claus brings about materialism, we go further to look at how and why the complete Christmas myth encourages and sanctifies materialism. Materialism can be defined as:

The importance a consumer attaches to worldly possessions. At the highest levels of materialism, such possessions assume a central place in a person's life and are believed to provide the greatest sources of satisfaction and dissatisfaction (Belk, 1984).

The link between happiness, fulfilment and goods, is illustrated here. The mythemes show such self-enhancement (good acquirement) linked with self-transcendent (good behaviour) values (Kilbourne and LaForge, 2010). But what of the consequences of materialism? Belk (1985) identifies possessiveness, non-generosity and envy as traits of materialism. He identifies the dual-messages children receive to be unselfish but also look after their possessions. Previous studies (Emler and Rushton, 1974; Handlon and Gross, 1959) have found that materialism decreases the older children get, because younger children must acquire possessions to overcome their dependence on adults (Furby, 1978).

Burroughs and Rindfleisch (2002) suggest that materialistic and collective/other oriented values are opposed to one another, cause tension and lower wellbeing. However for Christmas these values coexist to ease tension between such incongruent values. We find pictures which show both materialistic aspects (toys) and collective-oriented values such as religious (Advent reefs, nativity scenes) and/or family elements. This may be partly to do with no real good versus evil theme in the Christmas mythemes. However, with the lack of actual consequences for children at Christmas time, this responsibility aspect is weakened, allowing for greater levels of congruence as any sort of behaviour is given goods and it becomes a right instead of a reward.

Further, the merging of the baby Jesus with the effigy of the Christkind, which is directly translated as the Christ child, helps settle the incongruence between selflessness as associated with Jesus and selfish good acquisition as associated with the Christkind. The Christkind is the bringer of gifts. Where the representation of the Christkind is the opposite of Jesus - male versus female, dark features versus light, brown versus blond hair, angel versus human - prevents blaspheming. Commonly myths are used by marketers to promote such magical thinking, especially as they help to remedy social contradictions (Holt, 2006). Thus we can clearly see for children that the suggested opposition of 
materialistic with collective behaviour (Burroughs and Rindfleisch, 2002) is more like a coexistence in the context of Christmas.

Theoretical implications of this research surround the broadening of the concept of proximal processes from (Bronfenbrenner, 1995) which are processes used by children to develop an understanding of the environment around them and which influence them as individuals. While previous research stated that such exploration resulted in goals and values (Bronfenbrenner and Ceci, 1994), this research provides an alternative avenue of how these processes occur within consumption contexts and marketer controlled environments. The interpretation of mythemes by children into functional components of their understanding of their relationships to others, the physical world, universe and the supernatural/unknown contributes alternative paths to human development than previously presented in the literature.

\section{Ethical considerations considering Christmas marketing to children}

Scott et al. (2014) identify the magical thinking that marketers perpetuate in consumers that goods acquisition solves all of life's problems and gains happiness (Belk et al., 2003). Myths used by marketers promote such magical thinking, especially as they help to remedy social contradictions (Holt, 2006) such as we see with the mythemes identified in this study. Materialistic values can be seen to be positive as they support the economy (Muncy and Eastman, 1998). However, encouraging materialism is socially irresponsible because it teaches that happiness is gained through good acquisition instead of social relationships or other life achievements (Hudders and Pandelaere, 2012; Richins and Fournier, 1991). But materialism only really becomes a problem when consumption or acquisition of goods becomes more important than everything else in a person's life (Belk, 1985; Richins and Dawson, 1992).

In considering the ethical implications of our findings we reflect on Ross (1930) prima facie duties as the most logically appropriate ethical base for this situation. Ross (1930) prima facie duties provide a set of obligatory rules for behaviour and are in no particular ranking. In fact, Ross encourages their user to apply common sense and use the most important duty for a situation if duties contradict at any point.

The duty of non-maleficence, to do no harm, leads us to conclude that it is unethical for marketers to deliberately encourage materialism in children by using the Christmas myth. This assertion is also supported by Kant's (1785) Principle of Humanity and Garrett's (1966) Proportionality Framework. For instance, Kant's Principle of Humanity relates that one should never treat a person as merely a means to an end. Thus, an advertiser using the Christmas mythemes just to increase the materialistic nature of children, ultimately to gain profit, would be seen as being unethical. Likewise, as an extension of Kantian ethics, Garrett's Proportionality Framework asks three questions to judge whether an action is ethical or not. Firstly, is what is willed as either a means or an end to cause a major evil? If an advertiser willed for more materialistic children so they could grow into materialistic adults, so they might benefit from profit, given the negative consequences shown from materialism that may well illustrate an unethical behaviour. However, if they instead willed other things, such as education or fun, this would not be seen as unethical. Secondly, what are the unwilled side effects? And are there proportionate reasons for allowing a negative side effect? Here again, we might see that the marketers use of Christmas mythemes with an unintended side effect of materialism and less well-being, might also be seen as unethical. The last question asks: is there an alternative action that would circumvent the negatives of an action? If that alternative was not selected that is also seen as unethical.

Given the negative impacts of materialism on people's well-being and society in general, we are led to believe that it is unethical for marketers to emphasise, teach and encourage materialism through the use of Christmas mythemes. However, banning marketers use of 
Christmas mythemes altogether might be going a bit far, as there are some very positive mythemes present for marketers to use instead. We might here apply the duty of beneficence to the situation, which is the obligation to benefit others in our actions (Ross, 1930). It would be more ethical for marketers to emphasise the less materialistic mythemes or aspects of Christmas mythemes. For instance, marketers could emphasise the family and other-centred values that are present in the mythemes of selflessness. How products can be used as a family, between siblings or friends specifically could be shown in advertising. This instead of an emphasis on the self-transcendent values of playing alone for personal pleasure (hedonism) and personal gifts to increase status, power and provide personal happiness. Instead, such a focus on the social linking values of their products (Cova, 1997), consuming as experiencing life situations, to integrate into groups, to play and interact with others and learn about themselves (Holt, 1995) can be emphasised.

\section{Conclusion}

In conclusion, this article has gone beyond current literature on children's Christmas letters which tend to provide content analysis and descriptions of the letters. Instead, it has undertaken an in-depth conceptual analysis and provided theoretical explanations of the areas of influence that Christmas mythemes surround. As such, this article has uncovered Christmas mythemes for Austrian children as: Earthly/Material and Transcendental; Selfish and Selfless; and Rewards and Punishments. In exploring their representation and functions in children's Christmas letters we were able to discuss the mythemes role in the formation of a child's consumption culture within our conceptual framework relating those functions as proximal processes. As such, within a child's micro, meso and exosystems, both psychological and sociological guidance can be gained from mytheme functions. While within a child's macrosystem environment, both cosmological and metaphysical guidance can be interpreted. Specifically, we have found that the Christmas mythemes blend to relieve tensions between their paradoxical base values. As a result, the values are blended to justify materialism. Advertiser's use of these mythemes to encourage materialism has been reasoned to be unethical. Not just in and of itself, but because less harmful Christmas mythemes are available to them. It is suggested that more of a focus on the linking values, experiential functions and self-learning aspects of their products would be a more ethical course.

\section{Limitations and future research}

This research is limited due to its nature. We unintrusively collated letters thus cannot gauge actual behaviour or attitudes of the children. Future research in this area might therefore include qualitative as well as quantitative data collection in the form of interviews, focus groups or surveys to measure the level of influence mythemes have on each area of functioning and on human development overall.

\section{References}

Barnett, J.H. (1954), The American Christmas, a Study in National Culture, reprint Edition 1984, Ayer Company, Publishers, North Stratford, $\mathrm{NH}$.

Bartunek, J.M. and DO, B. (2011), "The sacralization of Christmas commerce", Organization, Vol. 18 No. 6, pp. 795-806.

Belk, R.W. (1984), "Three scales to measure constructs related to materialism: reliability, validity and relationships to measures of happiness", Advances in Consumer Research, Vol. 11, pp. 291-297.

Belk, R.W. (1985), "Materialism: trait aspects of living in the material world", Journal of Consumer Research, Vol. 12 No. 3, pp. 265-280. 
Belk, R.W. (1987), "A child's Christmas in America: Santa Claus as deity, consumption as religion”, The Journal of American Culture, Vol. 10 No. 1, pp. 87-100.

Belk, R.W. (1993), "Materialism and the making of the modern American Christmas", in Miller, D. (Ed.) Unwrapping Christmas, Clarendon Press, Oxford.

Belk, R.W., Ger, G. and Askegaard, S. (2003), "The fire of desire: a multi sited inquiry into consumer passion", Journal of Consumer Research, Vol. 30 No. 3, pp. 326-351.

Bettelheim, B. (1976), The Uses of Enchantment: The Meaning of Fairy Tales, Vintage, New York, NY.

Blanchet, V. (2020), "Happy Christmases are all alike; each unhappy Christmas is unhappy in its own way", Marketing Theory, Vol. 20 No. 2, pp. 175-184.

Brauer, J. (2019), "'Stille nacht' time and again: Christmas songs and feelings", in Klassen, P.E. and Scheer, M. (Eds), The Public Work of Christmas: Difference and Belonging in Multicultural Societies, Mc Gill Queen's University Press, Montreal.

Broeckerhoff, A. and Galalae, C. (2020), "Christmas markets - marketplace icon", Consumption Markets \& Culture, pp. 1-12.

Brofenbrenner, U. (1979), The Experimental Ecology of Human Development, Harvard University Press, Cambridge, MA.

Bronfenbrenner, U. (1995), "Developmental ecology through space and time: a future perspective", in Moen, P., Elder, G.H. and Lüscher, K. (Eds), Examining Lives in Context: Perspectives on the Ecology of Human Development, APA Science Volume Series, Washington, DC.

Bronfenbrenner, U. and Ceci, S.J. (1994), "Nature-nuture reconceptualized in developmental perspective: a bioecological model", Psychological Review, Vol. 101 No. 4, p. 568.

Broom, D. (2019), "Christmas, by the numbers: 5 facts about holiday season spending [online]", available at: www.weforum.org/agenda/2019/12/christmas-holiday-season-shopping-retail-gifts/

Buijzen, M. and Valkenburg, P.M. (2000), "The impact of television advertising on children's Christmas wishes", Journal of Broadcasting \& Electronic Media, Vol. 44 No. 3, pp. 456-470.

Burroughs, J.E. and Rindfleisch, A. (2002), "Materialism and well-being: a conflicting values perspective", Journal of Consumer Research, Vol. 29 No. 3, pp. 348-370.

Campbell, J. (1970), "Mythological themes in creative literature and art", in Campbell, J. (Ed.), Myth, Dreams and Religion, EP Dutton \& Co., New York, NY.

Caplow, T. (1982), "Christmas gifts and kin networks", American Sociological Review, Vol. 47 No. 3, pp. 383-392.

Caplow, T. (1984), "Rule enforcement without visible means: christmas gift giving in Middletown", American Journal of Sociology, Vol. 89 No. 6, pp. 1306-1323.

Caron, A. and Ward, S. (1975), "Gift decisions by kids and parents", Journal of Advertising Research, Vol. 15, pp. 15-20.

Carrier, J. (1993), "The rituals of Christmas giving", in Miller, D. (Ed.), Unwrapping Christmas, Oxford University Press, Oxford.

Clarke, P. (2007), "A measure for Christmas spirit", Journal of Consumer Marketing, Vol. 24 No. 1, pp. 8-17.

Cova, B. (1997), "Community and consumption", European Journal of Marketing, Vol. 31 Nos 3/4, pp. 297-316.

Cram, F. and Ng, S.H. (1999), "Consumer socialisation", Applied Psychology, Vol. 48 No. 3, pp. 297-312.

Crotty, M. (1998), The Foundations of Social Research: Meaning and Perspective in the Research Process, Sage, California.

Darling, N. (2007), "Ecological systems theory: the person in the center of the circles", Research in Human Development, Vol. 4 Nos 3/4, pp. 203-217.

Dautovic, G. (2020), "Christmas spending statistics: deck the halls with boughs of money [online]", available at: https://fortunly.com/statistics/christmas-spending-statistics/\#gref

Deacy, C. (2016), Christmas as Religion: rethinking Santa, the Secular and the Sacred, Oxford University Press, Oxford. 
Dotson, M.J. and Hyatt, E.M. (2000), "A comparison of parents' and children's knowledge of brands and advertising slogans in the United States: implications for consumer socialization", Journal of Marketing Communications, Vol. 6 No. 4, pp. 219-230.

Downs, A.C. (1983), "Letters to Santa Claus: elementary school-age children's sex-typed toy preferences in a natural setting", Sex Roles, Vol. 9 No. 2, pp. 159-163.

Eisenmann, J.C., Gentile, D.A., Welk, G.J., Callahan, R., Strickland, S., Walsh, M. and Walsh, D.A. (2008), "SWITCH: rationale, design and implementation of a community, school and family-based intervention to modify behaviors related to childhood obesity", BMC Public Health, Vol. 8 No. 1, p. 110.

Emler, N.P. and Rushton, J.P. (1974), "Cognitive-developmental factors in children's generosity", British Journal of Social and Clinical Psychology, Vol. 13 No. 3, pp. 277-281.

Frye, N. (1957), Anatomy of Criticism: Four Essays, Princeton University Press, reprint 2020, New Jersey.

Furby, L. (1978), "Possession in humans: an exploratory study of its meaning and motivation", Social Behavior and Personality: An International Journal, Vol. 6 No. 1, pp. 49-65.

Ganassali, S. (2019), "Status of brands in children's consumption: what letters to Santa posted on La poste website tell us", Psychology \& Marketing, Vol. 36 No. 1, pp. 5-14.

Garrett, T. (1966), Business Ethics, Prentice Hall, Englewood, NJ.

Gill, J. and Papatheodorou, T. (1999), "Perpetuating the father Christmas story: a justifiable lie?", International Journal of Children's Spirituality, Vol. 4 No. 2, pp. 195-205.

Hagstrom, W.O. (1966), "What is the meaning of Santa Claus?", The American Sociologist, pp. 248-252.

Halkoaho, J. and Laaksonen, P. (2009), "Understanding what Christmas gifts mean to children", Young Consumers, Vol. 10 No. 3, pp. 248-255.

Handlon, B.J. and Gross, P. (1959), "The development of sharing behavior", The Journal of Abnormal and Social Psychology, Vol. 59 No. 3, p. 425.

Hayta, A.B. (2008), "Socialization of the child as a consumer", Family and Consumer Sciences Research Journal, Vol. 37 No. 2, pp. 167-184.

Hirschman, E.C. (1987), "Movies as myths: an interpretation of motion picture mythology", in UmikerSebeok, J. (Ed.), Marketing and Semiotics: New Directions in the Study of Signs for Sale, Walter de Gruyter, Berlin.

Hirschman, E.C. (1988), "The ideology of consumption: a structural-syntactical analysis of 'Dallas' and 'dynasty', Journal of Consumer Research, Vol. 15 No. 3, pp. 344-359.

Hirschman, E.C. and Labarbera, P.A. (1989), "The meaning of Christmas", Interpretive Consumer Research, Vol. 1, pp. 136-147.

Holt, D.B. (1995), "How consumers consume: a typology of consumption practices", Journal of Consumer Research, Vol. 22 No. 1, pp. 1-16.

Holt, D.B. (2006), “Jack Daniel's America: iconic brands as ideological parasites and proselytizers", Journal of Consumer Culture, Vol. 6 No. 3, pp. 355-377.

Hudders, L. and Pandelaere, M. (2012), "The silver lining of materialism: the impact of luxury consumption on subjective well-being”, Journal of Happiness Studies, Vol. 13 No. 3, pp. 411-437.

John, D.R. (1999), "Consumer socialization of children: a retrospective look at twenty-five years of research", Journal of Consumer Research, Vol. 26 No. 3, pp. 183-213.

Kant, I. (1785), The Moral Law: Groundwork of the Metaphysic of Morals, Psychology Press reprint 2005, Routledge, London and New York.

Kearney, R. (1991), "Between tradition and utopia: the hermeneutical problem of myth", in Wood, D. (Ed.), On Paul Ricóur: Narrative and Interpretation, Routledge, London and New York.

Kilbourne, W.E. and Laforge, M.C. (2010), "Materialism and its relationship to individual values", Psychology \& Marketing, Vol. 27 No. 8, pp. 780-798.

Kriechbaum, R. (2010), Weihnachtsbräuche in Österreich, Pustet, Salzburg.

Laing, J. and Frost, W. (2015), "Christmas traditions", Rituals and Traditional Events in the Modern World, pp. 103-126. 
Lévi-Strauss, C. (1955), "The structural study of myth", The Journal of American Folklore, Vol. 68, pp. 428-444.

Lévi-Strauss, C. (1963), Structural Anthropology, Basic Books, New York, NY.

Lévi-Strauss, C. (1993), Father Christmas Executed, in Miller, D. (Ed.), Unwrapping Christmas, Clarendon Press, Oxford.

Levy, S.J. (1981), "Interpreting consumer mythology: a structural approach to consumer behavior", Journal of Marketing, Vol. 45 No. 3, pp. 49-61.

Lincoln, Y.S. and Guba, E.G. (1985), Naturalistic Inquiry, Sage, Newberry Park. CA.

Martínez-Pastor, E., Nicolás-Ojeda, M.-Á. and Salas-Martínez, Á. (2013), "Gender representation in advertising of toys in the Christmas period (2009-12)", Comunicar, Vol. 21 No. 41, pp. 187-194.

Mckay, G.A. (2008), "Consumption, coca-colonisation, cultural resistance-and Santa Claus", in Whiteley, S. (Ed.), Christmas, Ideology and Popular Culture, Edinburgh University Press, Edinburgh.

Mckechnie, S. and Tynan, C. (2006), "Social meanings in Christmas consumption: an exploratory study of UK celebrants' consumption rituals", Journal of Consumer Behaviour, Vol. 5 No. 2, pp. 130-144.

Miles, C.A. (1912), Christmas in Ritual and Tradition, Christian and Pagan, TF Unwin, London.

Miller, D. (2017), "Christmas: an anthropological lens", HAU: Journal of Ethnographic Theory, Vol. 7 No. 3 , pp. 409-442.

Moschetti, G.J. (1979), "The Christmas potlatch: a refinement on the sociological interpretation of gift exchange", Sociological Focus, Vol. 12 No. 1, pp. 1-7.

Muncy, J.A. and Eastman, J.K. (1998), "Materialism and consumer ethics: an exploratory study", Journal of Business Ethics, Vol. 17 No. 2, pp. 137-145.

O'Cass, A. and Clarke, P. (2002), "Dear Santa, do you have my brand: a study of the brand requests, awareness and request styles at Christmas time", Journal of Consumer Behaviour, Vol. 2 No. 1, pp. 37-53.

Otnes, C., Kim, Y.C. and Kim, K. (1994), "All I want for Christmas: an analysis of children's brand requests to Santa Claus", The Journal of Popular Culture, Vol. 27 No. 4, p. 183.

Pimlott, J.A.R. (1962), "But once in a year", New Society, Vol. 12, pp. 9-12.

Pine, K.J. and Nash, A. (2002), "Dear Santa: the effects of television advertising on young children", International Journal of Behavioral Development, Vol. 26 No. 6, pp. 529-539.

Pine, K.J., Wilson, P. and Nash, A.S. (2007), "The relationship between television advertising, children's viewing and their requests to father Christmas", Journal of Developmental \& Behavioral Pediatrics, Vol. 28 No. 6, pp. 456-461.

Pollay, R.W. (1987), "It's the thought that counts: a case study in Xmas excesses", ACR North American Advances, Vol. 14, pp. 140-143.

Prentice, N.M., Manosevitz, M. and Hubbs, L. (1978), "Imaginary figures of early childhood: santa Claus, Easter bunny and the tooth fairy", American Journal of Orthopsychiatry, Vol. 48 No. 4, p. 618.

Richardson, J.G. and Simpson, C.H. (1982), "Children, gender and social structure: an analysis of the contents of letters to Santa Claus", Child Development, Vol. 53 No. 2, pp. 429-436.

Richins, M. and Fournier, S. (1991), "Some theoretical and popular notions concerning materialism", Journal of Social Behavior and Personality, Vol. 6, pp. 403-414.

Richins, M.L. and Dawson, S. (1992), "A consumer values orientation for materialism and its measurement: scale development and validation", Journal of Consumer Research, Vol. 19 No. 3, pp. 303-316.

Ridenour, A. (2016), The Krampus and the Old, Dark Christmas: roots and Rebirth of the Folkloric Devil, Feral House, Port Townsend, WA.

Robertson, T.S. and Rossiter, J.R. (1976), "Short-run advertising effects on children: a field study", Journal of Marketing Research, Vol. 13 No. 1, pp. 68-70.

Ross, W.D. (1930), The Right and the Good, Oxford University Press, Oxford.

Scheer, M. (2019), "Tense holidays: approaching Christmas through conflict", in Klassen, P.E. and Scheer, M. (Eds), The Public Work of Christmas: Difference and Belonging in Multicultural Societies, McGill Queen's University Press, Montreal. 
Schori, K. (2008), "Aussagen von Kindern und Eltern zur Rolle der Geschenke an Weihnachten", in Baumann, M. and Hauri, R. (Eds), weihnachten: familienritual zwischen tradition und kreativität, Kohlhammer, Stuttgart.

Schwartz, S.H. (1994), "Are there universal aspects in the structure and contents of human values?", Journal of Social Issues, Vol. 50 No. 4, pp. 19-45.

Scott, K., Martin, D.M. and Schouten, J.W. (2014), "Marketing and the new materialism", Journal of Macromarketing, Vol. 34 No. 3, pp. 282-290.

Sherry, J.F. (1987), "Advertising as a cultural system", in Umiker-Sebeok, J. (Ed.), Marketing and Semiotics: New Directions in the Study of Signs for Sale, Walter de Gruyter, Berlin.

Stern, B.B. (1995), "Consumer myths: Frye's taxonomy and the structural analysis of consumption text", Journal of Consumer Research, Vol. 22 No. 2, pp. 165-185.

Theobald, M., Busch, G. and Danby, S. (2018), "Socializing children into pop culture: a visit to Santa", Global Studies of Childhood, Vol. 8 No. 3, pp. 252-266.

Thompson, C.J. (2004), "Marketplace mythology and discourses of power", Journal of Consumer Research, Vol. 31 No. 1, pp. 162-180.

Tynan, C. and Mckechnie, S. (2005), "Sacralising the profane: creating meaning with Christmas consumption in the UK", ACR European Advances, Vol. 7, pp. 182-188.

Vernaleken, T. (1859), Mythen und Bräuche des Volkes in Oesterreich: als Beitrag zur deutschen Mythologie, Volksdichtung und Sittenkunde, W. Braumüller, Wien.

Ward, S. (1974), "Consumer socialization”, Journal of Consumer Research, Vol. 1 No. 2, pp. 1-14.

Weber-Kellermann, I. (1978), Das Weihnachtsfest: Eine Kultur-und Sozialgeschichte der Weihnachtszeit, Bucher, Luzern.

Witkowski, T.H. (2020), "Guns for Christmas: advertising in boys' life magazine, 1911", Journal of Macromarketing, Vol. 40 No. 3, pp. 396-414.

Wolf, E.R. (1964), Santa Claus: notes on a Collective Representation, Aldine, Chicago.

\section{Appendix}

\section{Story bases of Christmas myth}

The base story of Jesus' birth is that he was the only son of God and was born of a virgin named Mary who was betrothed to a man named Joseph who was from the line of King David (Matthew 1:18-23 NIV). Joseph took a pregnant Mary back to his birthplace which was Bethlehem in Judea, for a census. Jesus was born in a barn and laid in a manger because there were no rooms available in Bethlehem (Luke 2:1-7 NIV). Nearby, an angel appeared and told some shepherds who then went to see the baby who was the saviour of the world (Luke 2:8-18 NIV). In Jerusalem, three Magi/Wise Men from the east followed a star until it stopped over the place where Jesus was in Bethlehem. They worshipped him and gave him gifts of gold, for the crowning of a King; incense, for worship; and myrrh - a sign of mortality (Matthew 2:1-12 NIV; Miles, 1912; Deacy, 2016; Miller, 2017).

Santa Claus is said to live in the North Pole with his elves who make toys for all of the children in the world. He lives with his wife Mrs Claus and they do not have any children. He wears a red fur trimmed coat, a big black belt on his baggy pants, with mittens and a stocking cap. He is a large, jolly fellow with a rosy complexion, a white beard and moustache and a round belly who laughs by saying "ho ho ho". On Christmas Eve, Santa delivers toys to every child around the world in a magical sleigh pulled by eight flying reindeer. He lands on rooftops and climbs down chimneys to lay gifts under the tree. He magically never runs out of toys to deliver, even though he only has one big sack of them, and it only takes him one night to get to every child in the world. He has a list of all the children in the world, and it tells whether they have been "naughty" or "nice" over the year. It is said that "naughty" children do not get toys but receive coal instead; however, this very rarely happens. He is happy to receive letters from the children of the world with their Christmas wishes and tries to grant their wishes (Nast 1890 [1978], Author, 1963; Sundblom 1931; Coots and Gillespie, 1934; Moore 1822 [2013]; Deacy, 2016). 
St Nicholas was a 4th century Bishop in Myra, Turkey. It is said that he gave a gift of gold to a father who was going to have to sell his daughters into prostitution. Each night for three nights, he snuck to the man's house and threw a sack of gold in his window. One for each of the man's three daughters. The bags of gold served as dowry for the girls so they could instead get married (De Groot, 1965; Shlien, 1959; Ridenour, 2016). St. Nicholas was up to the 16th century one of the main figures of the Christmas festivities, as he was the original gift bringer (Kriechbaum, 2010). Contrary to places such as The Netherlands where Sinterklaas brings presents on Christmas day. In Austria, St. Nicholas comes on 6 December. Similar to Santa, St Nicholas has a record of good and bad deeds for each child. Thus good children get rewarded, while naughty children are punished (Miles, 1912; Ridenour, 2016). Also, this tradition was intensified in the $1800 \mathrm{~s}$ as showed in Hoffmann's (1858) Struwwelpeter.

In many cases and particularly in Austria, St. Nicholas is accompanied by another figure which represents punishment of naughty children. In Austria, this figure is called "Krampus" or "Klaubauf" and often takes the form of the devil or a demonic creature (Kriechbaum, 2010; Vernaleken, 1859; Ridenour, 2016). Children are often threatened that the Krampus will take them away from their parents. Such stories are similar to Fink's (1957) collection of rural sagas: A farmer's wife wishes to scare her naughty son into behaving, so she asks the farmhand to dress as the Krampus and come and scare him. That night, the Krampus comes to the door, and the wife lets him take the boy thinking he is the farm hand. Only when the farmhand comes to the door later that night dressed as the Krampus does she realise that the real Krampus has taken her child to hell forever.

Luther introduced the Christkind during the reformation to shift the focus from St Nicholas day on 6 December to Jesus on 25 December (Schori, 2008; Ridenour, 2016). Originally, the Christkind represented the newborn Christ, but since the middle 1800s, the Christkind became "girlish" with an angel or fairy like portrayal. It wears a white and gold dress, with long curly blond hair and has a crown or golden diadem (Eberspächer, 2002). The Christkind fulfils the duty of mystically bringing presents on Christmas eve (a good depiction of the more girlish Christkind can be seen in the illustrations in Struwelpeter in Hoffmann, 1858, www.gutenberg.org/files/24571/24571-h/24571-h.htm). The Christkind does not have a list of naughty and nice children but instead observes them. Though she is not visible to children, if they are good and go to bed on Christmas eve, she will decorate the Christmas tree and bring them presents for Christmas day (Schori, 2008); this tradition and story is particularly created through popular Christmas poems from the 1800s, e.g. poems both named "Das Christkind" from Robert Reinick 1845 or Anna Ritter Das Christkind 1898. Also the intro page of the Struwelpeter shows the relationship of the Christkind as a present bringer (https://www.gutenberg.org/files/24571/24571-h/24571-h. htm)

\section{References for Appendix}

Coots, F. and Gillespie, H. (1934), "Santa Claus is coming to town".

De Groot, A.D. (1965), Saint Nicholas: A Psychoanalytic Study of His History and Myth, Vol. 1, Walter de Gruyter, The Hague and Paris.

Deacy, C. (2016), Christmas as religion: rethinking Santa, the secular and the sacred, Oxford University Press, Oxford.

Eberspächer, M. (2002), Der Weihnachtsmann: zur Entstehung Einer Bildtradition in Aufklärung Und Romantik, BoD-Books on Demand, Norderstedt.

Fink, H. (1957), Eisacktaler Sagen, Bräuche, Ausdrücke, Schlern-Schrift Nr. 164, Innsbruck.

Hoffmann, H. (1858), Struwwelpeter, Courier Corporation, Frankfurt.

Kriechbaum, R. (2010), Weihnachtsbräuche in Österreich, Pustet, Salzburg.

Miles, C.A. (1912), Christmas in Ritual and Tradition, Christian and Pagan, TF Unwin, London.

Miller, D. (2017), "Christmas: an anthropological lens", HAU: Journal of Ethnographic Theory, Vol. 7 No. 3 , pp. 409-442.

Moore, C.C. (1822 [2013]), The Night before Christmas, Little, Brown Books for Young Readers, Random House, New York.

Nast, T. (1890 [1978]), Thomas Nast's Christmas Drawings, Courier Corporation, New York. 
Nast, T. (1963), "Merry old Santa Claus”, Harpers Weekly, New York.

Ridenour, AL. (2016), The Krampus and the Old, Dark Christmas: roots and Rebirth of the Folkloric Devil, Feral House, Port Townsend, WA.

Schori, K. (2008), "Aussagen von Kindern und Eltern zur Rolle der Geschenke an Weihnachten", in Baumann, M. and Hauri, R. (Eds), Weihnachten: Familienritual Zwischen Tradition Und Kreativität, Kohlhammer, Stuttgart, pp. 95-116.

Shlien, J. (1959), "Santa Claus: the myth in America", A Review of General Semantics, Vol. 16 No. 4, pp. 389-400.

Sundblom, H. (1931), "A depiction of Santa Claus holding a bottle of Coca-Cola", Painting for the CocaCola Company.

Vernaleken, T. (1859), Mythen Und Bräuche Des Volkes in Oesterreich: als Beitrag Zur Deutschen Mythologie, Volksdichtung Und Sittenkunde, W. Braumüller, Wien.

\section{Corresponding author}

Martin Waiguny can be contacted at: martin.waiguny@fh-krems.ac.at

For instructions on how to order reprints of this article, please visit our website: www.emeraldgrouppublishing.com/licensing/reprints.htm

Or contact us for further details: permissions@emeraldinsight.com 